\title{
ОСОБЛИВОСТІ КОМУНІКАТИВНОЇ ВЗАЕМОДІЇ УЧАСНИКІВ БУЛІНГУ В ПІДЛІТКОВОМУ ВІЦІ
}

\section{Максъом Катерина Володимирівна \\ Старший викладач кафедри сочіальної роботи Чернігівського начіонального технологічного університету, м. Чернігів (Украӥна)}

Анотація. У статті аналізуються особливості комунікативної взаємодії підлітків, які задіяні в процесі шкільного булінгу. Звертається увага на роль комунікативної установки та типу ставлення до оточення у виявленні булінгу серед підлітків.

Представлено результати емпіричного дослідження, в результаті якого підтверджено, по-перше, щу існує взаємозв'язок комунікативних схильностей респондентів підліткового віку 3 вербальною агресією. По-друге, виявлено, щзо на особливості комунікативної взаємодії учасників булінгу в підлітковому віці здійснюють вплив такі чинники як комунікативна установка та ставлення до оточуючих. В результаті емпіричного дослідження підтверджено, щзо існують значні відмінності у показниках комунікативної установки та типу ставлення до оточуючих серед респондентів, які виступають активними учасниками булінгу в шкільному середовищі («агресори» та «жертви») та іншими учнями підліткового віку, щзо мають змогу спостерігати за даним явищем. Проаналізовано можливі причини і наслідки таких розбіжностей.

Ключові слова: булінг, міжособистісна комунікація, комунікативні схильності, комунікативна установка, тип ставлення до оточуючих, підлітковий вік, шкільне середовище, цьккування.

Постановка проблеми. Головний фактор розвитку особистості підлітка - зростання соціальної активності. Питання міжособистісної комунікації з ровесниками в підлітковому віці набуває особливого значення. Та окрім відомої кризи підліткового віку, що викликає складні, суперечливі переживання підлітка, що зумовлюють труднощі його виховання та негативні прояви поведінки (впертість, грубість, негативізм, агресивність, дратівливість) [3], досить часто формуватися гармонійній особистості заважає і такий складний соціальний феномен як булінг. Вивчаючи проблему булінгу у школі, більшість вчених дійшли висновку, що найнебезпечнішим у цьому явищі $\epsilon$ наслідки. Варто зазначити, що вони познача- 
ються не лише на жертві, а на усіх учасниках цього процесу. Зокрема, у дітей, які стають об'єктами булінгу, це явище спричиняє низку психологічних проблем, а саме: депресію, низьку самооцінку, проблеми зі здоров'ям, низьку успішність, суїцидальні думки. Для таких дітей школа стає місцем постійних випробувань. Учні, з яких постійно знущаються, виявляють небажання ходити до школи, їх успішність знижується. Також вони можуть ставати замкнутими, надмірно тривожними, недовірливими.

Зважаючи на те, що переслідувачами у школі є ще діти, стає зрозумілим, що без виховного впливу на їх особистісний розвиток вони мають великі шанси у дорослому житті стати психопатологічною особистістю.

Аналіз останніх досліджень і публікацій. В сучасній науці існує декілька підходів до вивчення булінгу. Одні дослідники зосереджують увагу на пошуку й визначенні особистісних рис, характерних для певних учасників булінгу.Інші розглядають булінг як соціальнопсихологічний процес. Серед перших систематичних досліджень даного явища заслуговують на увагу наукові праці скандинавських (Д. Ольвеус, А. Пікас, Е. Роланд, Е. Мунте та ін.) та британських вчених (В. Бесаг, Д. Лейн, Д. Таттум, В. Ортон та ін.), в яких наводиться визначення булінгу, проаналізовано особистісні риси основних учасників, розглянуто можливі причини і наслідки даного явища. В Україні за даними дослідження, що було прове- дено Дитячим фондом ООН (ЮНІСЕФ) в лютому 2017 року, 67\% дітей у віці від 11 до 17 років стикалися з проблемою булінгу протягом останніх трьох місяців, що підтверджує актуальність досліджень цієї проблеми.

У вітчизняній науці проблема булінгу тільки починає досліджуватись. Зокрема, можна виділити наукові праці таких авторів як К. Абслямова[1], А. Борщевська[2], С. Стельмах[9], Л.Лушпай[7] та ін., в яких досліджуються вікові особливості проявів булінгу, уточнюються типові риси основних учасників, а також досліджуються причини і наслідки булінгу. Щодо особливостей комунікативної взаємодії підлітків заслуговують уваги наукові праці Л. Петько [8], О. Корніяки [5], В. Кузьменко та Г. Міськової[6], О. Касьянової [4] та ін.

Мета статті. Виявлення особливостей комунікативної взаємодії «жертв» i «агресорів»- основних учасників булінгу.

Виклад основного матеріалу і результатів дослідження. Численні якісні та кількісні зміни в організмі та у психіці підлітка кардинально впливають на особливості його взаємин з оточуючими. Провідною діяльністю, в якій формується центральне новоутворення особистості підлітка, виступає інтимноособистісне спілкування. Спілкування з ровесниками набуває для підлітка особливої значущості. 3 ровесниками підліток може повною мірою відчувати себе дорослим - самостійним і незалежним. Саме в цей період підліток усві- 
домлює своє право на повагу, самостійність, довіру з боку оточуючих, проявляє інтерес до своєї індивідуальності, розмірковує про себе. Джерелом інтересу, при цьому, є прагнення відповідати вимогам оточуючих, усвідомити свої недоліки, що заважають спілкуванню (H. I. Гуткіна). Тому провідна функція самосвідомості підлітка - соціально-регуляторна [3]. Досить часто формуванню гармонійної всебічно розвиненої особистості заважає складний соціальний феномен - булінг.

Булінг - це специфічна форма комунікативної взаємодії агресивного характеру, при якій сильніша (авторитетніша) особа (або група осіб) систематично і цілеспрямовано перес- користані методи теоретичного аналізу та емпіричні методи (анкета I.O. Фурманова[10], методика діагностики комунікативної установки В. В. Бойко [12], методика діагностики міжособистісних стосунків Т. Лірі (ДМС) і методика виявлення комунікативних та організаторських схильностей (КОС-2) за Б. Федоришиним і В. Синявським).

За результатами анкетування було виявлено, що найпоширенішою формою третирування серед учнів загальноосвітніх закладів 12-15 років є вербальне, що проявляється через прояви вербальної агресії, а саме: у образливих прізвиськах; насміханні над виглядом, видом діяльності, поведінкою дітей, які виріз-

Таблиия 1.

\section{Поширеність окремих видів віктимізації та агресії серед учнів середньої школи} (12-15 років)

\begin{tabular}{|c|c|c|c|}
\hline Шкали агресії & Поширеність & Шкали віктимізації & Поширеність \\
\hline Фізична & $20,1 \%$ & Фізична & $17,1 \%$ \\
\hline Вербальна & $44,8 \%$ & Вербальна & $36,4 \%$ \\
\hline Соціальна & $20,6 \%$ & Соціальна & $27,4 \%$ \\
\hline Напади на власність & $14,5 \%$ & Напади на власність & $19,1 \%$ \\
\hline
\end{tabular}

лідує іншу (слабшу, аутсайдера). Даний феномен $є$ досить поширеним у всьому світі, має складну рольову структуру та різні форми прояву. Основними учасниками даного процесу є «агресори» та «жертви». Тому в нашому емпіричному дослідженні у розрахунках фігурують саме представники цих двох груп, а третю групу представляють всі інші учні.

Для проведення дослідження були ви- няються серед однолітків; погрозах, приниженнях тощо. Такий розподіл можна пояснити віком респондентів - відбувається зміна форм прояву знущань з відкритих фізичних на вербальні, а згодом на непрямі прояви.

Дані по шкалам анкети представлені у таблиці 1.

Аналіз результатів дослідження комунікативних та організаторських схильностей 
дав змогу порівняти показники представників сформованих нами груп: «жертв», «агресорів» та «інших учнів».

Виявлено, що низький рівень комунікативних схильностей показали $33 \%$ респондентів, які входять до групи «агресори», $22 \%$ респондентів, які входять до групи «жертви» та 17\% респондентів, які входять до групи «інші учні». Також, рівень комунікативних схильностей, що нижчий за середній було виявлено серед $15 \%$ респондентів групи «агресори», 20\% респондентів групи «жертви» та 20\% респондентів, які входять до групи «інші учні».

Підлітки 3 низьким та нижче середнього рівнями прояву комунікативних та організаторських здібностей не прагнуть до спілкування, почувають себе невпевнено, напружено у новій компанії чи колективі, переважно проводять час наодинці із собою, обмежують власні знайомства, відчувають складності у встановленні контактів 3 людьми, уникають виступів перед аудиторією, погано орієнтуються у незнайомій ситуації, не відстоюють власної думки, важко переживають образи. Виявлення ініціативи у суспільній діяльності у них майже відсутнє, а прийняття самостійних рішень спостерігається дуже рідко, тому вони потребують постійної підтримки та спрямованості з боку інших.

Середній рівень комунікативних схильностей показали $15 \%$ респондентів, які входять до групи «агресори», 23\% респондентів, які входять до групи «жертви» та 17\% респондентів, які входять до групи «інші учні».

Для досліджуваних, що показали середній рівень розвитку комунікативних схильностей характерними рисами $є$ прагнення до контакту з людьми, відстоювання власної думки, планування роботи. Однак, потенціал цих схильностей не відзначається високою стійкістю.

Високий рівень прояву комунікативних схильностей було виявлено у $11 \%$ респондентів, які входять до групи «агресори», $12 \%$ респондентів, які входять до групи «жертви» та 20\% респондентів, які входять до групи «інші учні». Дуже високий рівень прояву вищеозначених структурних компонентів було виявлено у $26 \%$ респондентів, які входять до групи «агресори», 23\% респондентів, які входять до групи «жертви» та $26 \%$ респондентів, які входять до групи «інші учні». Це свідчить про те, що вони легко знаходять друзів, постійно прагнуть розширювати коло своїх знайомих, займаються суспільною діяльністю, допомагають близьким, друзям, проявляють ініціативу у спілкуванні. Їм притаманна швидка орієнтація у складних ситуаціях, невимушеність поведінки в новому колективі. Такі діти ініціативні та самостійні у прийнятті важливих рішень, вносять жвавий інтерес у незнайому компанію, полюбляють організовувати різ- 
номанітні ігри та заходи, наполегливі у діяльності, яка їх приваблює. Згідно із внутрішнім прагненням, вони самі шукають такі справи, які б задовольняли їх потребу в комунікативній та організаторській діяльності.

Отримані дані були піддані процедурі стандартної математико-статистичної обробки за допомогою програми SPSS 19.0 for Windows.

У результаті кореляційного аналізу статистично значущих взаємозв'язків між шкалами агресивності/віктимізації та рівнем комунікативних схильностей не було виявлено. Це можна пояснити тим, що найпоширеніша форма третирування у підлітковому віці вербальна, що, в свою чергу, від активних його учасників вже потребує певного рівня комунікативних схильностей. Таким чином, потрібно дослідити окремі компоненти комунікативної взаємодії підлітків.

Дуже важливими для формування культури спілкування є комунікативні установки, оскільки вони допомагають встановити контакт між співрозмовниками, підготувати їх до позитивного сприймання інформації, перебороти байдуже чи негативне ставлення до тих чи інших ідей, людей, ситуацій. Під впливом спілкування з різними людьми комунікативні установки виникають, змінюються і зникають.

За визначенням В. В. Бойко, комунікативна установка особистості являє собою певну готовність реагувати певним чином на ті чи інші типи партнерів по взаємодії, що зумовлено наявним досвідом спілкування, оцінками та переживаннями їх суті, поглядів та поведінки. Установка, за визначенням автора, визначається як кліше реагування, звичка відповідати певним способом на знайомі життєві ситуації, повторювані соціальні явища, та типи людей. Комунікативна установка виступає носієм психічної енергії та економить психічні та фізичні ресурси.

Основними компонентами комунікативних установок виступають:

1) знання про певні типи партнерів по спілкуванню (можуть бути істинними, сумнівними або хибними);

2) переживання досвіду спілкування 3 конкретними типами партнерів (може бути глибоким, неглибоким та поверхневим);

3) оцінювання конкретних типів партнерів (позитивні, негативні чи нейтральні);

4) прагнення виявити установки до конкретних типів партнерів.

Комунікативні установки суб'єктивні за своєю природою, або ж сформовані на основі знань, прагнень, оцінок самої особистості. Свідомий чи несвідомий прояв комунікативної установки особистості направлений на партнерів по спілкуванню несе потік позитивної чи негативної енергії, що є основою для формування позитивної чи негативної комунікативної установки.

Позитивна комунікативна установка визначається як готовність особистості добро- 
зичливо ставитись до більшості оточуючих. Формується під впливом сприятливого особистого досвіду взаємодії з іншими, внаслідок позитивних переживань та оцінювання більшості життєвих епізодів спілкування. конкретних учасників спільної діяльності.

Для визначення особливостей прояву комунікативної установки ми використали методику діагностики комунікативної установки за В. В. Бойко, яка виявляє насамперед

Табличя 2.

Середні показники рівня прояву негативної комунікативної установки у групах «агресори», «жертви» та «інщі учні»

\begin{tabular}{|c|c|c|c|c|}
\hline $\begin{array}{c}\text { Компоненти негативної } \\
\text { комунікативної установки }\end{array}$ & $\begin{array}{c}\text { Середні показ- } \\
\text { ники по всій } \\
\text { вибірці }\end{array}$ & $\begin{array}{c}\text { Середні показ- } \\
\text { ники групи } \\
\text { «агресори» }\end{array}$ & $\begin{array}{c}\text { Середні показни- } \\
\text { ки групи } \\
\text { «жертви» }\end{array}$ & $\begin{array}{c}\text { Середні показ- } \\
\text { ники групи } \\
\text { «інші учні» }\end{array}$ \\
\hline $\begin{array}{c}\text { Завуальована жорстокість } \\
\text { (максимум-20б.) }\end{array}$ & 11,2 & 14,4 & 15,1 & 7,2 \\
\hline $\begin{array}{c}\text { Відкрита жорстокість } \\
\text { (максимум-45б.) }\end{array}$ & 22,8 & 22,9 & 32,2 & 17,4 \\
\hline $\begin{array}{c}\text { Обгунтований негативізм } \\
\text { (максимум - 5б.) }\end{array}$ & 2,7 & 3,1 & 2,4 & 2,6 \\
\hline $\begin{array}{c}\text { Бурчання } \\
\text { (максимум - 10б.) }\end{array}$ & 1,6 & 2,4 & 1,7 & 1,1 \\
\hline $\begin{array}{c}\text { Негативний особистий досвід } \\
\text { (максимум-20б.) }\end{array}$ & 9,1 & 11,7 & 11,6 & 6,1 \\
\hline Загальний показник \\
(максимум-100б.)
\end{tabular}

Негативна комунікативна установка відображає готовність недоброзичливо ставитись до більшості оточуючих та формується під впливом несприятливого досвіду людської взаємодії, а також внаслідок яскраво виражених емоцій негативного характеру.

У повсякденній взаємодії комунікативна установка відіграє важливу роль у ставленні до людей в цілому. Вона формується у особистості під впливом всього досвіду спілкування, знань та оцінок більшості людей з якими довелося зустрічатися в різних сферах - у побуті, на роботі, у громадських місцях. Поступово зміцнюючись на свідомому чи несвідомому рівні установка «керує» сприйняттям рівень прояву негативної комунікативної установки стосовно інших людей, адже саме негативна комунікативна установка відображає готовність недоброзичливо ставитись до більшості оточуючих.

Аналіз результатів дослідження за даною методикою (Таблиця 2) виявив, що загальний середній показник комунікативної установки вищий за норму, це у свою чергу, засвідчує наявність вираженої негативної комунікативної установки у більшості респондентів. Також, аналізуючи дані по групам, простежується значно вищі середні показники у основних учасників третирування у порівнянні 3 іншими учнями. 
Тобто, у основних учасників булінгу «жертв» та «агресорів»- дуже високий рівень прояву негативної комунікативної установки, що відображає їх готовність недоброзичливо ставитись до більшості оточуючих. У підлітків, які $є$ основними учасниками процесу булінгу, негативна комунікативна установка могла сформуватися під впливом несприятливого досвіду людської взаємодії, а також внаслідок яскраво виражених емоцій негативного характеру. У респондентів, які входять до групи «інші учні», показник рівню негативної кому- мозв'язків негативних комунікативних установок зі шкалами агресивності/віктимізації.

3 високим показником рівню агресивності у групі «агресори» пов'язані такі компоненти негативної комунікативної установки, як:

- завуальована жорстокість;

- $\quad$ відкрита жорстокість (Таблиця 3).

Отримані нами результати вказують на сильний прямий взаємозв'язок між високим рівнем агресивності та компонентами негативної комунікативної установки, які свідчать

Взаємозв'язок високого рівню агресивності з компонентами негативної комунікативної установки у групі «агресори»

\begin{tabular}{|c|c|c|}
\hline \multirow{2}{*}{$\begin{array}{c}\text { Компоненти негативної комунікати- } \\
\text { вної установки }\end{array}$} & \multicolumn{2}{|c|}{ Загальний показник агресивності } \\
\cline { 2 - 3 } & Показник кореляції & Рівень значущості \\
\hline Завуальована жорстокість & 0,921 & $\mathrm{p} \leq 0,01$ \\
\hline Відкрита жорстокість & 0,838 & $\mathrm{p} \leq 0,01$ \\
\hline
\end{tabular}

нікативної установки значно відрізняється, але теж вищий за норму, що пояснюється негативним впливом булінгу на всіх членів групи.

Математико-статистичний аналіз отриманих даних за допомогою кореляційного аналізу підтвердив статистичну значущість взає- про те, що респонденти групи «агресори»не приховують своїх негативних оцінок та переживань з приводу більшості оточуючих, але не завжди можуть відкрито показати свою незадоволеність, агресію чи ворожість, тому часто використовують непрямі форми прояву аг-

Таблиця 4.

Взаємозв'язок високого рівню віктимізації з компонентами негативної комунікативної установки у групі «жертви»

\begin{tabular}{|c|c|c|}
\hline \multirow{2}{*}{$\begin{array}{c}\text { Компоненти негативної комуніка- } \\
\text { тивної установки }\end{array}$} & \multicolumn{2}{|c|}{ Загальний показник віктимізації } \\
\cline { 2 - 3 } & Показник кореляції & Рівень значущості \\
\hline Обгрунтований негативізм & 0,419 & $\mathrm{p} \leq 0,05$ \\
\hline
\end{tabular}


peciï.

3 загальним показником віктимізації пов'язаний такий компонент негативної комунікативної установки, як обгрунтований негативізм (Таблиця 4).

Прямий взаємозв'язок між рівнем вік- даному процесі по деяким компонентам негативної комунікативної установки (Таблиця 5).

Таким чином, такі основні компоненти негативної комунікативної установки як: завуальована жорстокість у стосунках з оточуючими, відкрита жорстокість у стосунках з оточу-

Таблиия 5.

\section{Середні показники рівню прояву негативної комунікативної установки у основних учасників третирування (групи «жертви» та «агресори») та інших учнів}

\begin{tabular}{|c|c|c|c|}
\hline $\begin{array}{c}\text { Компоненти негативної } \\
\text { комунікативної установ- } \\
\text { ки }\end{array}$ & $\begin{array}{c}\text { Середні показни- } \\
\text { ки основних уча- } \\
\text { сників третиру- } \\
\text { вання }\end{array}$ & $\begin{array}{c}\text { Середні показники } \\
\text { групи «інші учні» }\end{array}$ & $\begin{array}{c}\text { Рівень значущості } \\
\text { відмінностей 3а t- } \\
\text { критерієм Ст'- } \\
\text { юдента }\end{array}$ \\
\hline $\begin{array}{c}\text { Завуальована жорстокість } \\
\text { (максимум - 20б.) }\end{array}$ & 14,7 & 7,2 & $\mathrm{p} \leq 0,01$ \\
\hline $\begin{array}{c}\text { Відкрита жорстокість } \\
\text { (максимум - 45б.) }\end{array}$ & 27,4 & 17,4 & $\mathrm{p} \leq 0,01$ \\
\hline $\begin{array}{c}\text { Бурчання } \\
\text { (максимум - 10б.) }\end{array}$ & 2,1 & 1,1 & $\mathrm{p} \leq 0,01$ \\
\hline $\begin{array}{c}\text { Негативний особистий дос- } \\
\text { від } \\
\text { (максимум - 20б.) }\end{array}$ & 11,7 & 6,1 & $\mathrm{p} \leq 0,01$ \\
\hline
\end{tabular}

тимізації та обгрунтованим негативізмом в думках про людей виражається в об'єктивно обумовлених негативних висновках респондентів, які входять до групи «жертви», про деякі типи людей та окремі сторони взаємодії. Тобто, «жертви» не чекають нічого хорошого від оточуючих, налаштовані на конфліктну взаємодію.

За допомогою t-критерія Ст'юдента було виявлено статистично достовірну різницю $(\mathrm{p} \leq 0,01)$ між показниками респондентів, що $\epsilon$ основними учасниками булінгу (група «жертви» та група «агресори») та групою «інші учні», що не беруть активної участі у ючими, бурчання, тобто схильність до необумовленого узагальнення негативних чинників у сфері стосунків 3 партнерами і у спостереженні за соціальною дійсністю, негативний особистий досвід спілкування 3 оточуючими, більш виражені у основних учасників третирування (групи «жертви» та «агресори») і рівень їх прояву значно відрізняється від рівню прояву основних компонентів негативної комунікативної установки у респондентів, які входять до групи «інші учні».

Як ми бачимо, основні компоненти негативної комунікативної установки взаємопов'язані з різноманітними формами прояву бу- 
лінгу, а рівень їх прояву у основних учасників булінгу значно вищий, ніж у їх однолітків.

Проаналізувавши результати дослідження за методикою діагностики міжособистісних стосунків Т. Лірі (Таблиця 6), ми виявили, що для респондентів, які входять до групи «агресори» найбільш притаманними типами ставлення до оточуючих $\epsilon$ успішних у своїх справах, вимогливих, прямолінійних, відвертих, суворих та різких в оцінці інших, схильних у всьому звинувачувати оточуючих. Такі підлітки відрізняються іронічністю та полюбляють глузувати з інших, в той час, як до себе потребують поважного ставлення.

Респонденти, які входять до групи

Таблиця 6.

Середні показники за методикою діагностики міжособистісних стосунків Т. Лірі

\begin{tabular}{|c|c|c|c|c|}
\hline $\begin{array}{c}\text { Типи ставлення до } \\
\text { оточуючих }\end{array}$ & $\begin{array}{c}\text { Середні показни- } \\
\text { ки по всій вибірці }\end{array}$ & $\begin{array}{c}\text { Середні пока- } \\
\text { зники групи } \\
\text { «агресори» }\end{array}$ & $\begin{array}{c}\text { Середні показ- } \\
\text { ники групи } \\
\text { «жертви» }\end{array}$ & $\begin{array}{c}\text { Середні по- } \\
\text { казники гру- } \\
\text { пи «інші } \\
\text { учні» }\end{array}$ \\
\hline Авторитарний & 7,5 & 9,9 & 5 & 7,4 \\
\hline Егоїстичний & 5,9 & 9,2 & 5,8 & 4 \\
\hline Агресивний & 6,1 & 10 & 5,2 & 4,3 \\
\hline Підозрілий & 6,7 & 5,4 & 11,2 & 4,9 \\
\hline Підкорений & 2,8 & 2,6 & 2,8 & 2,9 \\
\hline Залежний & 5,7 & 3,9 & 10,1 & 4,2 \\
\hline Дружелюбний & 8,2 & 6,4 & 7,4 & 9,8 \\
\hline Альтруїстичний & 5,7 & 5,8 & 5,8 & 5,5 \\
\hline
\end{tabular}

«авторитарний», «егоїстичний» та «агресивний». Для респондентів, які входять до групи «жертви» найбільш притаманними типами ставлення до оточуючих $\epsilon$ «підозрілий» та «залежний». Для респондентів, які входять до групи «інші учні» найбільш притаманним типом ставлення до оточуючих є «дружелюбний».

Такі результати характеризують респондентів, які входять до групи «агресори», як домінантних, енергійних, компетентних та «жертви», в даному випадку, характеризуються як критичні, нетовариські, невпевнені у собi, скептичні, замкнуті, слухняні, боязливі, часто безпорадні підлітки, які не вміють проявити опір і щиро вважають, що інші завжди праві.

Респонденти, які входять до групи «інші учні», відрізняються дружелюбністю та люб'язністю 3 усіма, зорієнтовані на приймання й соціальне схвалення, емоційнолабільні, прагнуть досягти цілей своїх мікрог- 
руп.

Кореляційний аналіз дав змогу виявити статистично-значущі взаємозв'язки (Таблиця 7) між високим рівнем прояву агресивності у респондентів групи «агресори» та певними типами ставлення до оточуючих. сердя, турботливість, тощо.

Підлітки з високим рівнем агресивності не схильні до: самоприниження, підкорення сильнішому без урахування ситуації, прийняття на себе відповідальності за інших.

Слід також пам'ятати, що високі показ-

Таблиця 7.

Взаємозв'язок високого рівню агресивності з типами ставлення до оточуючих у групі «агресори»

\begin{tabular}{|c|c|c|}
\hline \multirow{2}{*}{ Типи ставлення до оточуючих } & \multicolumn{2}{|c|}{ Загальний показник агресивності } \\
\cline { 2 - 3 } & Показник кореляції & Рівень значущості \\
\hline Авторитарний & 0,502 & $\mathrm{p} \leq 0,01$ \\
\hline Агресивний & 0,417 & $\mathrm{p} \leq 0,05$ \\
\hline Підкорений & $-0,713$ & $\mathrm{p} \leq 0,01$ \\
\hline Альтруїстичний & $-0,421$ & $\mathrm{p} \leq 0,05$ \\
\hline
\end{tabular}

Тобто, у респондентів, які входять до групи «агресори», 3 високим рівнем агресивності взаємопов'язані «авторитарний» та «агресивний» типи ставлення до оточуючих, що проявляється в: домінантності, енергійності, компетентності, успіхах у справах, любові до надання порад і потребі в повазі; в вимогливості, прямолінійності, відвертості, суворості та різкості в оцінці інших, схильності у всьому звинувачувати оточуючих, іронічності і любові до глузувань.

Також наявний зворотній взаємозв'язок 3 «підкореним» та «альтруїстичним» типами ставлення до оточуючих. Таким чином, чим вищий рівень прояву агресивності у респондентів, тим менш їм притаманні: покірність, пасивність, скромність, відповідальність, мило- ники по окремим типам ставлення до оточуючих свідчать про екстремальність інтерперсональної поведінки.

За допомогою t-критерія Ст'юдента було виявлено статистично достовірну різницю між показниками респондентів, що є основними учасниками булінгу (група «жертви» та група «агресори») та групою «інші учні», що не беруть активної участі у даному процесі по таким типам ставлення до оточуючих (Таблиця 8): «агресивний», «егоїстичний», «підозрілий», «залежний», «дружелюбний».

Для уточнення статистично значущих відмінностей за рівнем прояву окремих типів ставлення до оточуючих ми також порівняли за допомогою t-критерія Ст'юдента середні показники респондентів, які входять до груп 
Середні показники рівню прояву окремих типів ставлення до оточуючих у основних учасників третирування (групи «жертви» та «агресори») та інших учнів

\begin{tabular}{|c|c|c|c|}
\hline $\begin{array}{c}\text { Типи ставлення до оточу- } \\
\text { ючих }\end{array}$ & $\begin{array}{c}\text { Середні показни- } \\
\text { ки основних уча- } \\
\text { сників третиру- } \\
\text { вання }\end{array}$ & $\begin{array}{l}\text { Середні показники } \\
\text { групи «інші учні» }\end{array}$ & $\begin{array}{c}\text { Рівень значущос- } \\
\text { ті відмінностей за } \\
\text { t-критерієм Ст'- } \\
\text { одента }\end{array}$ \\
\hline Егоїстичний & 7,5 & 7,4 & $\mathrm{p} \leq 0,01$ \\
\hline Агресивний & 7,7 & 4,3 & $\mathrm{p} \leq 0,01$ \\
\hline Дружелюбний & 6,8 & 9,8 & $\mathrm{p} \leq 0,01$ \\
\hline Залежний & 7 & 4,2 & $\mathrm{p} \leq 0,01$ \\
\hline Підозрілий & 8,3 & 5 & $\mathrm{p} \leq 0,01$ \\
\hline
\end{tabular}

«агресори» та «інші учні». Було виявлено статистично достовірну різницю між показниками по таким типам ставлення до оточуючих (Таблиця 9): «агресивний»; «егоїстичний»; «авторитарний»; «дружелюбний».

Отже, отримані нами результати підт-

цьому процесі активну участь), значно в більшій мірі виражені такі типи ставлення до оточуючих, як: «агресивний», «егоїстичний», «авторитарний», на відміну від респондентів, які входять до групи «інші учні», яким притаманний «дружелюбний» тип ставлення до ото-

Таблиия 9.

Середні показники рівню прояву окремих типів ставлення до оточуючих у респондентів груп «агресори» та «інші учні»

\begin{tabular}{|c|c|c|c|}
\hline $\begin{array}{c}\text { Типи ставлення до оточу- } \\
\text { ючих }\end{array}$ & $\begin{array}{c}\text { Середні показни- } \\
\text { ки групи } \\
\text { «агресори» }\end{array}$ & $\begin{array}{c}\text { Середні показники } \\
\text { групи } \\
\text { «інші учні» }\end{array}$ & $\begin{array}{c}\text { Рівень значущості } \\
\text { відмінностей за t- } \\
\text { критерісм Ст'- } \\
\text { одента }\end{array}$ \\
\hline Агресивний & 10 & 4,3 & $\mathrm{p} \leq 0,01$ \\
\hline Егоїстичний & 9,2 & 4 & $\mathrm{p} \leq 0,01$ \\
\hline Авторитарний & 9,9 & 7,4 & $\mathrm{p} \leq 0,01$ \\
\hline Дружелюбний & 6,4 & 9,8 & $\mathrm{p} \leq 0,01$ \\
\hline
\end{tabular}

верджують, що у респондентів, які входять до групи «агресори» (учні, які розпочинають третирування жертви та в подальшому беруть у респондентів. чуючих. Це характеризує значні відмінності у стилях комунікативної взаємодії серед даних 
Також ми порівняли за допомогою tкритерія Ст'юдента середні показники респон- виступати в якості захисного механізму ізоляції від «жорсткого» навколишнього світу. На

Таблиця 10.

Середні показники рівню прояву окремих типів ставлення до оточуючих у респондентів груп «жертви» та «інші учні»

\begin{tabular}{|c|c|c|c|}
\hline $\begin{array}{c}\text { Типи ставлення до оточу- } \\
\text { ючих }\end{array}$ & $\begin{array}{c}\text { Середні показни- } \\
\text { ки групи } \\
\text { «жертви» }\end{array}$ & $\begin{array}{c}\text { Середні показники } \\
\text { групи } \\
\text { «інші учні» }\end{array}$ & $\begin{array}{c}\text { Рівень значущості } \\
\text { відмінностей за t- } \\
\text { критерієм Ст'- } \\
\text { юдента }\end{array}$ \\
\hline Залежний & 10,1 & 4,2 & $\mathrm{p} \leq 0,01$ \\
\hline Підозрілий & 11,2 & 4,9 & $\mathrm{p} \leq 0,01$ \\
\hline Авторитарний & 5 & 7,4 & $\mathrm{p} \leq 0,01$ \\
\hline Дружелюбний & 7,4 & 9,8 & $\mathrm{p} \leq 0,01$ \\
\hline Егоїстичний & 5,8 & 4 & $\mathrm{p} \leq 0,01$ \\
\hline
\end{tabular}

дентів, які входять до груп «жертви» та «інші учні». Було виявлено статистично достовірну різницю між показниками по таким типам ставлення до оточуючих (Таблиця 10): «підозрілий»; «егоїстичний»; «авторитарний»; «дружелюбний»; «залежний».

Отже, отримані нами результати підтверджують, що у респондентів, які входять до групи «жертви» (учні, які є об'єктами третирування), значно в більшій мірі виражені такі типи ставлення до оточуючих, як «залежний» i «підозрілий». За результатами кореляційного аналізу, проведеного нами раніше, саме 3 цими типами ставлення існує прямий взаємозв'язок у високого рівня віктимізації. Також виявлені відмінності за рівнем прояву «егоїстичного» типу ставлення до оточуючих. У респондентів групи «жертви» даний показник вищий, що можна пояснити егоїстичними рисами та направленістю на себе, що може відміну від «жертв», для респондентів, які входять до групи «інші учні», притаманний «дружелюбний» тип ставлення до оточуючих. Також виявлені відмінності за рівнем прояву «авторитарного» типу ставлення до оточуючих. У респондентів групи «інші учні» даний показник вищий, що можна пояснити нестачею самовпевненості, завзятості та лідерських якостей у респондентів, які входять до групи «жертви». Це характеризує значні відмінності у стилях комунікативної взаємодії серед даних респондентів.

Висновки. В результаті проведеного дослідження отримано наступні узагальнюючі положення:

1. В комунікативній взаємодії учасників булінгу учнів підліткового віку домінує вербальна агресія.

2. Існують відмінності в комунікативних установках активних учасників булінгу в 
шкільному середовищі («агресори» та «жертви») та іншими учнями підліткового віку, що мають змогу спостерігати за даним явищем.

3. На особливості комунікативної взаємодії учасників булінгу в підлітковому віці здійснює вплив тип їх ставлення до оточуючих.

Чинники особливостей комунікативної взаємодії учасників булінгу в підлітковому віці пов'язані 3 їх індивідуальнопсихологічними особливостями.

Перспективи подальших досліджень. Зважаючи на отримані результати, перспективним для подальших досліджень є розробка соціально-психологічної тренінгової програми для підлітків, спрямованої на розвиток комунікативних здібностей серед підлітків і протидію булінгу в шкільному середовищі.

\section{Перелік використаних джерел:}

1. Абсалямова К. З. Булінг у середовищі молодшої школи - соціально-психологічні й особистісні аспекти / К. 3. Абсалямова, О. Л. Луценко // Вісник Харківського національного університету імені В. Н. Каразіна. Серія : Психологія. - 2013. - № 1046, вип. 51. - С. 216221. - Режим доступу: http://nbuv.gov.ua/UJRN/ VKhIPC_2013_1046_51_50

2. Борщевська A. В. Булінг у школах як чинник психічного нездоров'я / А. В. Борщевська // Науковий вісник Міжнародного гуманітарного університету. Серія: Медицина. - 2014. -№6. - С.48-52.

3. Дуткевич T. В. Дитяча психологія: навч. посіб.

Т. В. Дуткевич. - К.: Центр учбової літератури, 2012. $424 \mathrm{c}$.
4. Касьянова О. В. Формування комунікативної компетентності молодших підлітків у громадських дитячих об'єднаннях: дис. канд. пед. наук: 13.00.07 / Ольга Володимирівна Касьянова. - К., 2011. - 224 с.

5. Корніяка О. М. Психологія комунікативної культури особистості школяра: дис. докт. псих. наук : 19.00.07 / Ольга Миколаївна Корніяка. - К., 2007. - 481 с.

6. Кузьменко В. У. Теоретичний аналіз проблеми розвитку комунікативних здібностей підлітків / В. У. Кузьменко, Г. А. Міськова // Міжнародний науковий форум: соціологія, психологія, педагогіка, менеджмент. - 2012. - Вип. 10. - С. 95-102. - Режим доступу: http://nbuv.gov.ua/UJRN/Mnf_2012_10_15.

7. Лушиай Л. I. Буллінг як соціально-педагогічна проблема та шляхи іiі вирішення (на прикладі досвіду середніх загальноосвітніх шкіл Великої Британії) [Електронний ресурс] / Л. І. Лушпай // Українознавчий альманах. - 2010. - Вип. 4. - С. 126-130. - Режим доступу: http://nbuv.gov.ua/j-pdf/Ukralm_2010_4_29.pdf.

8. Петько Л. В. Соціально-комунікативна активність підлітків: теорія і практика: монографія / Л. В. Петько. - К.: Ун-т «Україна», 2010. - 268 с.

9. Стельмах С. Булінг у школі та його наслідки / С. Стельмах // Гуманізація навчально-виховного процесу: збірник наукових праць / [За заг. ред. проф. В. І. Сипченка]. - Вип LVI. - Слов'янськ: СДПУ, 2011. - C. 431-440.

10. Фурманов И. А. Агрессия и насилие: диагностика, профилактика и коррекция / И. А. Фурманов. - СПб., 2007. $-480 \mathrm{c}$.

\section{References (Transliteration):}

1. Absaliamova K. Z. Bulinh u seredovyshchi molodshoi shkoly - sotsialno-psykholohichni y osobystisni aspekty / K. Z. Absaliamova, O. L. Lutsenko // Visnyk Kharkivskoho natsionalnoho universytetu imeni V. N. Karazina. Seriia : Psykholohiia. - 2013. - № 1046, vyp. 51. - S. 216-221. Rezhym dostupu: http://nbuv.gov.ua/UJRN/ VKhIPC_2013_1046_51_50 
2. Borshchevska A. V. Bulinh u shkolakh yak chynnyk psykhichnoho nezdorovia / A. V. Borshchevska // Naukovyi visnyk Mizhnarodnoho humanitarnoho universytetu. Seriia: Medytsyna. - 2014. -№6. - S.48-52.

3. Dutkevych T. V. Dytiacha psykholohiia: navch. posib. I T. V. Dutkevych. - K.: Tsentr uchbovoi literatury, 2012. $424 \mathrm{~s}$.

4. Kasianova $O . \quad V$. Formuvannia komunikatyvnoi kompetentnosti molodshykh pidlitkiv u hromadskykh dytiachykh obiednanniakh: dys. kand. ped. nauk: 13.00.07 / Olha Volodymyrivna Kasianova. - K., 2011. - 224 s.

5. Korniiaka O. M. Psykholohiia komunikatyvnoi kultury osobystosti shkoliara: dys. dokt. psykh. nauk : 19.00.07/ Olha Mykolaivna Korniiaka. - K., 2007. - 481 s.

6. Kuzmenko $V$. U. Teoretychnyi analiz problemy rozvytku komunikatyvnykh zdibnostei pidlitkiv / V. U. Kuzmenko, H. A. Miskova // Mizhnarodnyi naukovyi forum: sotsiolohiia, psykholohiia, pedahohika, menedzhment. 2012. - Vyp. 10. - S. 95-102. - Rezhym dostupu: http:// nbuv.gov.ua/UJRN/Mnf_2012_10_15.

7. Lushpai L. I. Bullinh yak sotsialno-pedahohichna problema ta shliakhy yii vyrishennia (na prykladi dosvidu serednikh zahalnoosvitnikh shkil Velykoi Brytanii) [Elektronnyi resurs] / L. I. Lushpai // Ukrainoznavchyi almanakh. - 2010. - Vyp. 4. - S. 126-130. - Rezhym dostupu: http://nbuv.gov.ua/j-pdf/Ukralm_2010_4_29.pdf.

8. Petko L. V. Sotsialno-komunikatyvna aktyvnist pidlitkiv: teoriia i praktyka: monohrafiia / L. V. Petko. - K.: Un-t «Ukraina», 2010. - $268 \mathrm{~s}$.

9. Stelmakh S. Bulinh u shkoli ta yoho naslidky / S. Stelmakh // Humanizatsiia navchalno-vykhovnoho protsesu: zbirnyk naukovykh prats / [Za zah. red. prof. V. I. Sypchenka]. - Vyp LVI. - Sloviansk: SDPU, 2011. - S. 431-440.

10. Furmanov $Y$. A. Ahressyia y nasylye: dyahnostyka, profylaktyka y korrektsyia / Y. A. Furmanov. - SPb., 2007. $-480 \mathrm{~s}$.

\section{Maksom Kateryna}

Lecturer of the Department of Social Work, Chernihiv National Technological University, Chernihiv (Ukraine)

\section{FEATURES OF COMMUNICATIVE INTERACTION OF MEMBERS OF THE BULLYING ACTIVITY IN ADOLESCENCE}

\section{ABSTRACT}

This article analyzes the features of communicative interaction of teenagers involved in the process of school bullying. Attention is drawn to the role of the communicative installation and the type of attitude to others in detecting the bullying among adolescents.

The results of the empirical study indicate that in the communicative interaction of the participants in the bullying of adolescent students dominated by verbal aggression and there is a correlation between the communicative inclinations of respondents of adolescence with verbal aggression. It was also revealed that on the features of communicative interaction of participants of the bullying in adolescents influenced by such factors as communicative installation and attitude to others. According to the empirical study, it has been confirmed that the main components of the negative communicative installation are interrelated with the various forms of the manifestation of the bullying, and their level of manifestation in the main participants of the bullying is much higher than that of their peers. Also proved that there are significant differences in terms of the attitude to others among the respondents who are active participants of the school bullying ("aggressor" and "victim") and other teenage stu- 
dents with an opportunity to observe this phenomenon. For respondents belonging to the group "aggressors", the most typical types of attitudes to others are "authoritarian", "selfish" and "aggressive", which characterizes this teenagers as dominant, energetic, demanding, straightforward, candid, severe and sharp in evaluating others, are inclined to blame all around. For respondents belonging to the "victim" group, the most common types of attitudes towards others are "suspicious" and "dependent", which characterizes them as critical, non-affiliate, unsure of themselves, closed, obedient, often helpless teenagers who cannot resist and sincerely believe that others are always right. For respondents belonging to the group "other students", the most common type of attitude to others is "friendly", which manifests itself in courtesy with all, orientation towards acceptance and social acceptance, aspiration to achieve the goals of their microgroups.

Possible causes and consequences of such differences are analyzed.

Key words: bullying, interpersonal communication, communicative inclinations, communicative setting, type of attitude to others, adolescence, school environment, harassment.

\section{Максьом Екатерина Владимировна}

Стариий преподаватель кафедры соичиальной работы Черниговского национального технологического университета, г. Чернигов (Украина)

\section{ОСОБЕННОСТИ КОММУНИКАТИВНОГО ВЗАИМОДЕЙСТВИЯ УЧАСТНИКОВ БУЛЛИНГА В ПОДРОСТКОВОМ ВОЗРАCTE}

Аннотация. В статье анализируются особенности коммуникативного взаимодействия подростков, задействованных в процессе школьного буллинга. Обращается внимание на роль коммуникативной установки и типа отношения к окружающим в выявлении буллинга среди подростков.

Представлены результаты эмпирического исследования, в результате которого установлено, что в коммуникативном взаимодействии участников буллинга у учащихся подросткового возраста доминирует вербальная агрессия и подтверждено, что существует взаимосвязь коммуникативных склонностей респондентов подросткового возраста с вербальной агрессией. Также выявлено, что на особенности коммуникативного взаимодействия участников буллинга в подростковом возрасте оказывают влияние такие факторы как коммуникативная установка и отношение к окружающим. По данным эмпирического исследования подтверждено, что основные компоненты негативной коммуникативной установки взаимосвязаны с различными формами проявления буллинга, а уровень их про- 
явления у основных участников буллинга значительно выше, чем у их сверстников. Также доказано, что существуют значительные различия в показателях типа отношения к окружающим среди респондентов, которые выступают активными участниками буллинга в школьной среде («агрессоры» и «жертвы») и другими учениками подросткового возраста, которые имеют возможность наблюдать за данным явлением. Для респондентов, которые входят в группу «агрессоры» наиболее характерными типами отношения к окружающим является «авторитарный», «эгоистичный» и «агрессивный», характеризующий данных подростков как доминантных, энергичных, требовательных, прямолинейных, откровенных, суровых и резких в оценке других, склонных во всем обвинять окружающих. Для респондентов, которые входят в группу «жертвы» наиболее характерными типами отношения к окружающим является «подозрительный» и «зависимый», что характеризует их как критичных, необщительных, неуверенных в себе, замкнутых, послушных, часто беспомощных подростков, не умеющих проявить сопротивление и искренне считающих, что другие всегда правы. Для респондентов, которые входят в группу «другие ученики» наиболее характерным типом отношения к окружающим является «дружелюбный», что проявляется в любезности со всеми, ориентированности на прием и социальное одобрение, стремлении достичь целей своих микрогрупп.
Проанализированы возможные причины и последствия таких различий в показателях.

Ключевые слова: буллинг, межличностная коммуникация, коммуникативные склонности, коммуникативная установка, тип отношения к окружающим, подростковый возраст, школьная среда, травля.

Дата отримання статті: 17.02 .2018 Дата рекомендації до друку: 23.02.2018 